\title{
Dynamic crop planning for enhancing crop productivity in Mymensingh district
}

\author{
T. Akter ${ }^{1^{*}}$, M. S. U. Talukder ${ }^{2}$, M. H. Rahman ${ }^{3}$ and M. N. N. Mazumder ${ }^{4}$ \\ ${ }^{1}$ Department of Irrigation and Water Management, Sylhet Agricultural University, Sylhet-3100, Bangladesh, \\ ${ }^{2}$ Department of Irrigation and Water Management, Bangladesh Agricultural University, Mymensingh 2202, \\ Bangladesh, ${ }^{3}$ BINA Substation, Rangpur Bangladesh Institute of Nuclear Agriculture and ${ }^{4}$ BINA Substation, Ishurdi, \\ Bangladesh Institute of Nuclear Agriculture, Bangladesh, *E-mail : tahminaiwm@yahoo.com
}

\begin{abstract}
A study was carried out to analyze the rainfall data for crop planning in rainfed regions,, Probability analysis of rainfall offers a better scope for predicting the minimum assured rainfall to help in crop planning. The $75 \%$ probability of rainfall occurrence was proposed as an index of dependable rainfall for crop production. Considering this in view, 25 years (1981-2005) of rainfall data of Mymensingh district have been analyzed in greater details covering probability aspects. Assured rainfall analysis, probability of potential evapotranspiration, water-balance approach and actual evapotranspiration were found quite effective to assess the water availability period for crop planning under rainfed condition. It was found that maximum rainfall occurred in July and minimum in December. The numbers of rainy days per year at $75 \%$ probability were 128 days. In the month of July and August numbers of rainy days were 20 and in December, it reduced to zero. The highest potential evapotranspiration was obtained in April (4.6 mm/day) and the lowest in January $(2.4 \mathrm{~mm} /$ day).It was observed that April to October is the rainfall excess (rainfall>PET) and November to March is the deficit period (PET>rainfall). Climatic water balance revealed the possibility of water harvesting during May to October. It may be concluded that probabilistic rainfall data and number of rainy days, would be quite helpful for crop planning. It provides useful information like land preparation, planting, transplanting, intercultural operations, harvesting, threshing, drying and other cropping practices. This would go a long way in crop planning at farmers and at policy making level.
\end{abstract}

Keywords: Rainfall, Probability analysis, Crop planning

\section{Introduction}

The uneven distribution of rainfall of Bangladesh sometimes creates unfavorable conditions for crop growth and agricultural droughts of varying intensities limit the crop production potential. The annual rainfall in the country ranges from 1400 to $5800 \mathrm{~mm}$ but its distribution is uneven (Manola, 1978). Ali et al. (1994) found that the average annual rainfall in the country was $2486 \mathrm{~mm}$. They also found that the average monsoon rainfall in every year was $66.76 \%$ of the total rainfall in the year. About 70 to $80 \%$ of the total annual rainfall occurs during the months from June to September, leaving the most productive dry season (November to March) with inadequate rainfall for crop growth. Also the months of April and May, have insufficient rainfall and crops suffer from significant periods of drought during monsoon season. The efficacy of rainfall for crop production is dependent on its adequacy, certainty and distribution. Even under improved management practices, most of the variation in crop yield can be explained by the use of analysis of weather elements. Rainfall is considered as a principal source of water (Vishwakarma et al., 2000). For deriving maximum benefit from dry land agriculture, one must have a proper knowledge of short period rainfall distribution both in time and space. In rainfed areas, the distribution pattern and amount of rainfall plays a very important role in crop planning. In our country, distribution of rainfall is very erratic and varies considerably from region to region and year to year. Fluctuations in the monsoon alone attribute approximately $30 \%$ variation in the grain production (BBS, 2004).In Bangladesh work on rainfall for crop planning has been done by many workers. However little work has been done in Mymensingh on probability studies of rainfall particularly for Agricultural planning. The parameters such as amount, intensity, spread of rainfall and number of rainy days are being used to characterize rainfall in a place. Among them rainfall distribution has been found to have profound effect on crop performance in rainfed agriculture. Long-term probability analysis can provide a basis for planning cropping pattern and water management strategy. Rainfall prediction can help farmers in determining best adapted plant species, the optimum time of ploughing and seeding, planning supplemental irrigation schemes, evaluation of alternative cropping and soil-water management plans and selection of harvesting time. 
The studies on variability in seasonal rainfall, probability analysis of varying duration, will provide useful information for evaluating the potential of climate to suggest the suitable cropping pattern and modify the management practices for agricultural development. Therefore, the present study was undertaken to analyse the rainfall data for crop planning.

Evapotranspiration is a measurement of the total amount of water used as evaporation and transpiration to grow crops. In order to estimate actual crop water requirements, the PET is corrected through the use of crop co-efficient $(\mathrm{kc})$. Actual evapotranspiration is the amount of water actually used by the crop.

Rainfall distribution pattern in relation to physiological phase of the crop variety and soil condition is a prerequisite for successful crop planning. The purpose of the study is to estimate potential evapotranspiration. From monthly values of evapotranspiration at $75 \%$ probability, actual evapotranspiration was also computed for specific crop. In winter or other seasons except the rainy season, there may be a deficiency of soil moisture in crop field, which requires irrigation.

\section{Materials and Methods}

\section{Site description and data collection}

The Mymensingh district is located on $24^{\circ} 46^{\prime} \mathrm{N}$ lattitude and $90^{\circ} 56^{\prime} \mathrm{E}$ longitude (Fig.1). This district is bounded by the Kingdom Meghalaya on the north and Gazipur district on the south, Netrokona and Kishoregang to the east and Sherpur, Jamalpur and Tangail to the west. Hilly regions of the district are covered by Sherpur and the Kingdom Tripura. Main river of this district is the Brahmaputra. Main crops of this district are rice, jute, wheat, potato, mustard, sugarcane and pulses. This region consists of $28 \%$ high land, 35\% medium high land and $20 \%$ medium low land, $7 \%$ low land and $10 \%$ homestead. General fertility level is low with medium phosphorus and cation exchange capacity status.

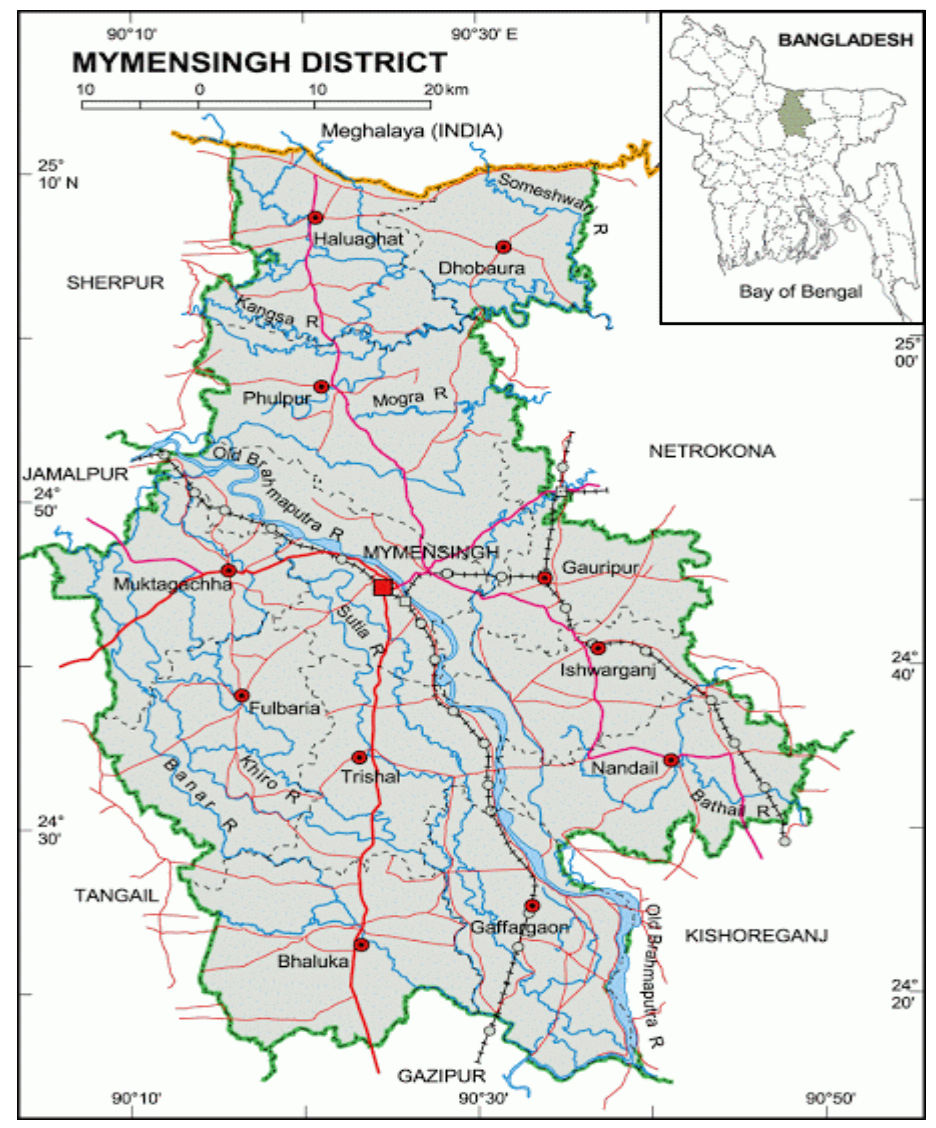

Fig.1. Map of Mymensingh district 
Major climatological data like rainfall, temperature, relative humidity, wind speed and sunshine hours for a period of 25 years were collected from the Meteorological Department of Bangladesh (MDB) situated at Agargaon in Dhaka. All the collected data were used for estimating monthly evapotranspiration and monthly total rainfall.

\section{Analysis of rainfall data}

The average rainfall and its variability in each month were computed considering the data of the 25 years (1981 to 2005). First, the monthly mean and standard deviations were calculated from these data and then the percentage co-efficient of variation was computed by the following formula.

$$
\begin{aligned}
& \text { C.V. }(\%)=\frac{\text { S.D }}{\bar{x}} \times 100 \\
& \text { where }, \\
& \text { C.V. }=\text { Co-efficient of variation } \\
& \text { S.D. }=\text { Standard deviation } \\
& \bar{x}=\text { Mean }
\end{aligned}
$$

The rainfall data were also used for determining the total number of rainy days, average rainy day per month and rainfall per rainy day. The most commonly used Weibull (1939) formula was used for probability analysis. According to this method, all the data were arranged in descending order for probabilities of exceedance. The values of return period, $\mathrm{T}$, were computed for the corresponding data using the Weibull formula:

$$
\mathrm{T}=\frac{\mathrm{n}+1}{\mathrm{~m}}
$$

where

$$
\begin{aligned}
& \mathrm{n}=\text { Total number of data } \\
& \mathrm{m}=\text { Order or Rank of the observation from the highest value }
\end{aligned}
$$

The probability, $\mathrm{P}$ is obtained as the inverse of the return period. The percentage probability of rainfall was also computed. Rainfall was plotted against the corresponding probability on the normal probability paper where it is drawn and the probability curves were drawn. These points were found to approximate a straight line which indicated in all cases that the distribution is approximately normal. The expected rainfall at percent probability level of $75 \%$ was estimated for the month of January to December.

\section{Monthly ETo calculation}

The FAO Penman-Monteith equation (Allen et al., 1998) was used to calculate the daily evapotranspiration for the different months:

$$
E T_{0}=\frac{0.408 \Delta \Delta(n-G)+\gamma \frac{900}{T+273} u_{2}\left(e_{s}-e_{a}\right)}{\Delta+\gamma\left(1+0.34 u_{2}\right)}
$$

where,

$$
\begin{aligned}
& \mathrm{ET}_{0}=\text { Reference crop evapotranspiration, } \mathrm{mm} / \text { day } \\
& \mathrm{R}_{\mathrm{n}}=\text { Net radiation at the crop surface, } \mathrm{MJ} / \mathrm{m}^{2} / \text { day } \\
& \mathrm{G}=\text { Soil heat flux density, } \mathrm{MJ} / \mathrm{m}^{2} / \text { day } \\
& \mathrm{T}=\text { Air temperature at } 2 \mathrm{~m} \text { height, }{ }^{\circ} \mathrm{C} \\
& \mathrm{u}_{2}=\text { Wind speed at } 2 \mathrm{~m} \text { height, } \mathrm{m} / \mathrm{sec} \\
& \mathrm{e}_{\mathrm{s}}=\text { Saturation vapour pressure, } \mathrm{kPa} \\
& \mathrm{e}_{\mathrm{a}}=\text { Actual vapour pressure, } \mathrm{kPa} \\
& \left(\mathrm{e}_{\mathrm{s}}-\mathrm{e}_{\mathrm{a}}\right)=\text { Saturation vapour pressure deficit, } \mathrm{kPa} \\
& \triangle=\text { Slope of vapour pressure curve, } \mathrm{kPa}{ }^{\circ} \mathrm{C}^{-1} \text { and } \\
& \gamma=\text { Psychometric constant, } \mathrm{kPa}{ }^{\circ} \mathrm{C}^{-1}
\end{aligned}
$$




\section{Actual evapotranspiration and Water requirement}

Doorenbos and Pruitt (1977) defined evapotranspiration as the quantity of water transpired by plants during their growth and that retained in the plant tissue plus the moisture evaporated from the surface of the soil and the vegetation. Evapotranspiration for some important crops were calculated by the following formula:

$\mathrm{ET}_{\text {crop }}=\mathrm{kc} . \mathrm{PET}$

where

$\mathrm{ET}_{\text {crop }}=$ Evapotranspiration of a particular crop, $\mathrm{mm} / \mathrm{month}$

$\mathrm{kc}=$ Crop co-efficient

$\mathrm{PET}=$ Potential evapotranspiration, $\mathrm{mm} /$ month

Water requirement of a crop is the quantity of water needed for normal growth, development and yield and may be supplied by precipitation or by irrigation or by both. Water is needed mainly to meet the demands of evaporation (E), transpiration $(\mathrm{T})$ and metabolic needs of the plants.

\section{Results and Discussion}

\section{Rainfall pattern and its variability}

Analysis of rainfall in Mymensingh districts revealed that $85 \%$ (Table 1) of the total average annual rainfall occurred during the monsoon period (April to October), and the remaining $15 \%$ were distributed in the pre-monsoon and post-monsoon periods, respectively. It was observed that the distribution of rainfall over the months of the year at all locations were quite uneven and erratic. Most rainy months were June, July and August while the least occurred in November. December, January and February. January is the driest month of the year. Similar results were found by Khan et al. (1991).

About $70 \%$ of the annual rainfall occurred during the months of June to September and $90 \%$ during May to October. The period between May to October is surplus period (rainfall>PET), and generally no problem is being faced with agricultural and other water-based activities. The major Kharif-I and Kharif-II crops during April to October of different locations of the country is rice, and there is no problem of water except special years, when dry spell continued for long time affecting crop growth. The months from November to March, and in some cases upto April is deficit period (rainfall<PET).But from the viewpoint of availability of solar energy, this period is best suited for crop production (Hossain et al., 2001).

Table 1. Number of rainy days per month, dependable rainfall (mm) and Potential evapotranspiration ( $\mathrm{mm} /$ day) at $75 \%$ probability of Mymensingh

\begin{tabular}{|l|c|c|c|}
\hline Month & Number of rainy days & $\begin{array}{c}\text { Dependable } \\
\text { rainfall }(\mathrm{mm})\end{array}$ & Potential evapotranspiration (mm/day) \\
\hline January & 2 & 9 & 2.41 \\
\hline February & 3 & 22 & 3.10 \\
\hline March & 4 & 47 & 4.00 \\
\hline April & 9 & 170 & 4.60 \\
\hline May & 15 & 360 & 4.40 \\
\hline June & 20 & 440 & 3.80 \\
\hline July & 25 & 490 & 3.50 \\
\hline August & 20 & 382 & 3.80 \\
\hline September & 20 & 180 & 3.30 \\
\hline October & 9 & 220 & 3.40 \\
\hline November & 1 & 24 & 3.00 \\
\hline December & 0 & 0 & 2.42 \\
\hline Total & 128 & 2344 & \\
\hline
\end{tabular}




\section{Distribution of Rainy Days over the Months}

Distribution of crops depends less on the rainfall received during a month than on its distribution which can be better studied with the help of the number of rainy days. A rainfall of less than $5 \mathrm{~mm}$ in a day with no rainfall on the previous or next day was considered to be of little use. The results (Table 1) indicated that the number of rainy days per year was 128 . That is only one day was rainy out of 3 days and or little more. Talukder et al (1988) also found that the number of rainy days per year at Dhaka was 116 which means that above one third of the days were rainy. The maximum number of rainy day per month at $75 \%$ probability was 20 in July and August and minimum number of rainy days was zero in the month of December.

\section{Probability analysis of rainfall and evapotranspiration}

It appears from the Fig.1. that for the 75 per cent probability, dependable rainfall values were greater than the mean values for almost all of the months of the year. The expectation of getting higher rainfall was from April to July. After July, expectation of higher rainfall started to decrease. Both maximum mean monthly rainfall and $75 \%$ dependable rainfall occurred in July.

The higher monthly dependable rainfall at 75 percent probability was observed in the month of July. It appears from Table 1 that the amount of monthly rainfall from May to October was higher. During dry season (Nov.-Mar.), the amount of rainfall was lower.

Monthly potential evapotranspiration (PET) was calculated by using the FAO Penman-Monteith equation. The values of PET at $75 \%$ probability obtained from normal probability paper are also presented in Table 1.

The highest PET, $4.6 \mathrm{~mm} /$ day, was obtained in April and May and the lowest $2.4 \mathrm{~mm} /$ day in January and December.

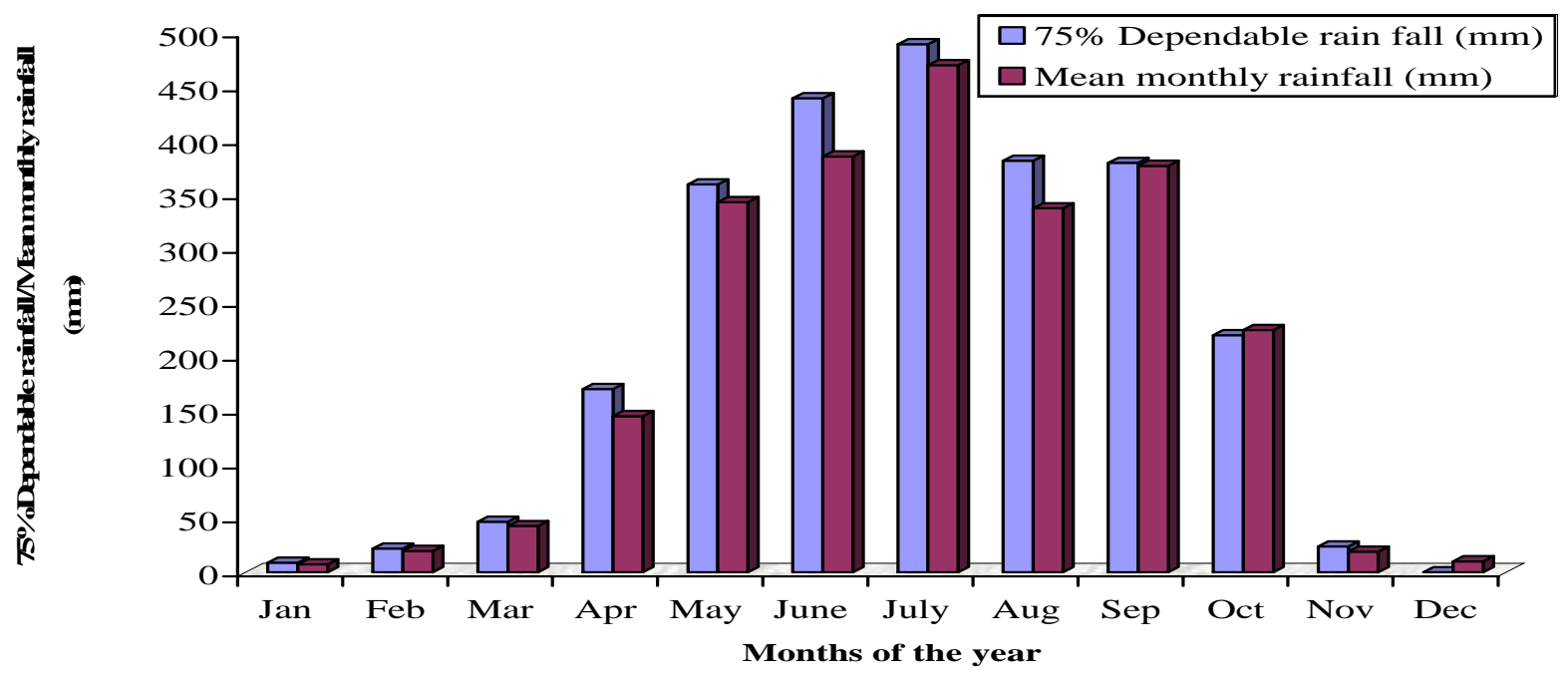

Fig. 2. Comparison between $75 \%$ dependable rainfall $(\mathrm{mm}) \mathrm{L}$ and mean monthly rainfall $(\mathrm{mm})$ at Mymensingh district

The results indicated that potential evapotranspiration started increase from February $(3.1 \mathrm{~mm} /$ day $)$ and continued up to April in almost all the stations studied. It can be seen that potential evapotranspiration gradually decreased from April to July. Then, it suddenly increased in August and after that, reached to its lowest value in January $(2.4 \mathrm{~mm} /$ day $)$.

The rainfall and evapotranspiration information would help in planning the crops to be grown, and irrigation, drainage, water storage and other facilities to be created for successful agricultural operation. 


\section{Water balance}

It was found from Fig. 3 that November to March remained under rainfall deficit condition (PET> Rainfall). So, irrigation was necessary in order to grow crops during this period because of non-availability of sufficient amount of rain water and high atmospheric evaporative demand by the crops. During the period from mid-April to mid-October, precipitation was much higher than potential evapotranspiration (Rainfall> $\mathrm{PET}=$ Rainfall excess). The present findings are in good agreement with the results reported by Talukder (1982).Efforts should be made to harvest the excess rain water in April to October in Canals, beels, ponds, rivers, etc or suitable storage structures and reuse it during the deficit periods and also use it for growing or cultivating crops in rabi season.

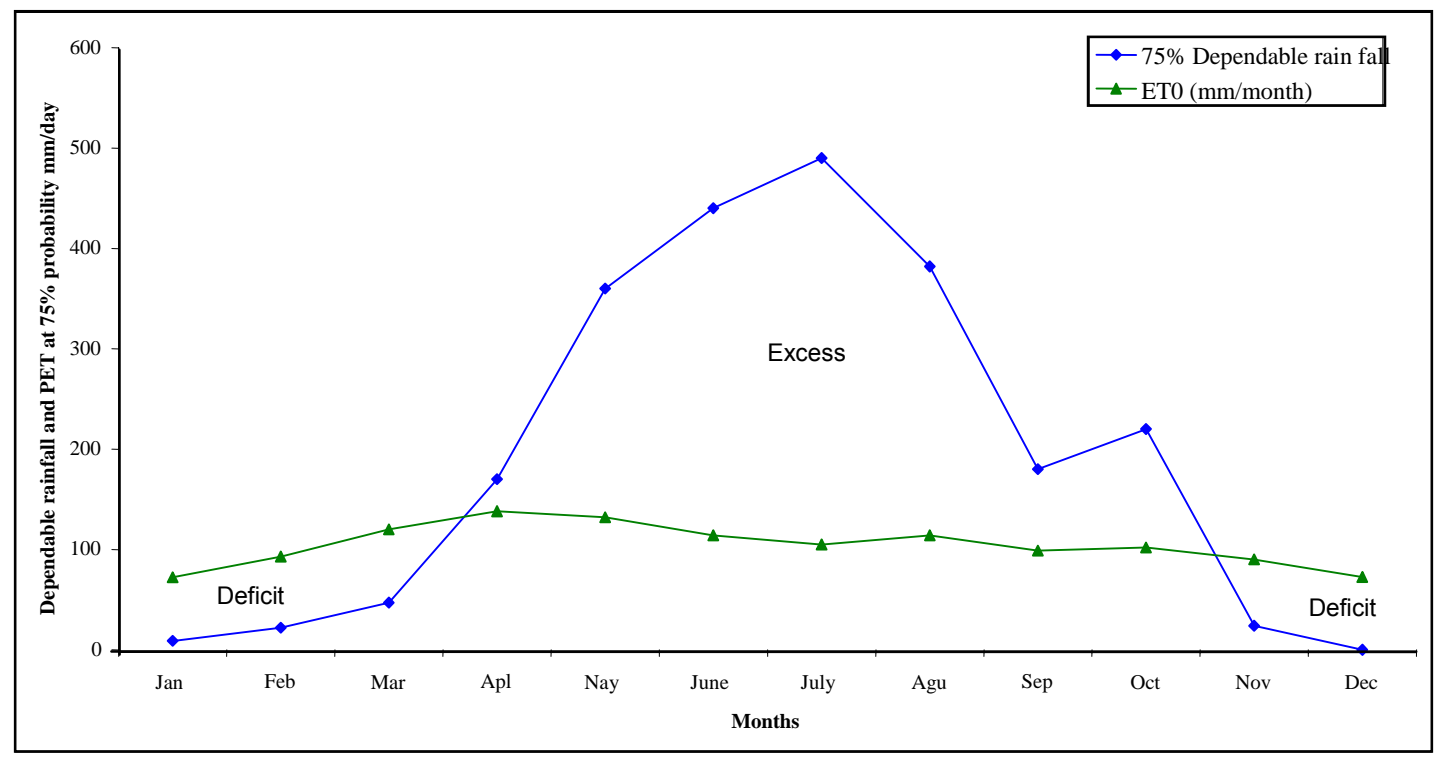

Fig. 3. $75 \%$ dependable monthly rainfall as compared with monthly potential evapotranspiration at $75 \%$ probability in Mymensingh

\section{Crop planning}

The rainfall at $75 \%$ assured level should be utilized for growing rainy-season crops like maize, cowpea, groundnut, blackgram and direct-seeded rice in second fortnight of June with the commencement of monsoon. There was continuous dry spell at the end of October which could be utilized for harvesting of rainy season crops and field preparations for winter season. High value winter crops could be grown only with supplemental irrigation during winter season, starting from November.

Table 2. Most important crops of Mymensingh district

\begin{tabular}{|l|c|c|}
\hline \multicolumn{1}{|c|}{ Rabi } & Kharif-I & Kharif-II \\
\hline $\begin{array}{l}\text { Wheat, potato, mustard, lentil, chickpea, onion, } \\
\text { cabbage, cauliflower etc. }\end{array}$ & Jute, ladies finger, Aus & T-Aman \\
\hline
\end{tabular}

The cropping patterns are based on rice. After harvesting the transplanted Aman rice at the end of October, farmers can grow pulse, oilseeds like mustard, groundnut, or wheat crop provided the stored moisture after rice (Kharif II) is utilized through immediate land preparation (by the middle of November).The establishment and development of rice plant, known as vegetative stage, water requirements of 120 day variety of Aus were found to be $180.60 \mathrm{~mm}$ but the $75 \%$ dependable rainfall was only $88 \mathrm{~mm}$. The entire reproductive stage is highly sensitive to water. Khan and Bhuiyan (1985) found that for rice, yield reduction due to a stress in reproductive stage was three times than that of vegetative stage. Water requirements at reproductive stage were found to be $262.30 \mathrm{~mm}$. At the reproductive stage, dependable rainfall $(75 \%)$ was much higher than water requirements. Good drainage should be provided to reduce water stagnation. Similar results were found by Doorenbos et al. (1979). 
Table 3. Water requirements of some important crops

\begin{tabular}{|l|c|c|c|c|c|c|c|c|}
\hline Crops & $\begin{array}{c}\text { Initial } \\
\text { stage } \\
(\mathrm{mm})\end{array}$ & $\begin{array}{c}75 \% \\
\text { depend- } \\
\text { able } \\
\text { rainfall } \\
(\mathrm{mm})\end{array}$ & $\begin{array}{c}\text { Develo- } \\
\text { pment } \\
\text { stage } \\
(\mathrm{mm})\end{array}$ & $\begin{array}{c}75 \% \\
\text { depend- } \\
\text { able } \\
\text { rainfall } \\
(\mathrm{mm})\end{array}$ & $\begin{array}{c}\text { Mid- } \\
\text { season } \\
\text { stage } \\
(\mathrm{mm})\end{array}$ & $\begin{array}{c}75 \% \\
\text { depend- } \\
\text { able } \\
\text { rainfall } \\
(\mathrm{mm})\end{array}$ & $\begin{array}{c}\text { Late- } \\
\text { season } \\
\text { stage } \\
(\mathrm{mm})\end{array}$ & $\begin{array}{c}75 \% \\
\text { depend- } \\
\text { able } \\
\text { rainfall } \\
(\mathrm{mm})\end{array}$ \\
\hline Wheat & 15.17 & 22 & 46.875 & 0 & 139.725 & 13 & 6.975 & 4 \\
\hline Potato & 31.68 & 94 & 65.03 & 44 & 86.25 & 0 & 31.88 & 10 \\
\hline Brinjal/ tomato & 33.65 & 0 & 84.00 & 18.57 & 204.13 & 105.14 & 92.00 & 170 \\
\hline Groundnut (Rabi) & 39.02 & 44 & 75.00 & 0 & 132.50 & 34 & 28.00 & 88 \\
\hline Maize (Kharif-1) & 24.80 & 24 & 96.00 & 88 & 211.6 & 283.33 & 0.00 & 227 \\
\hline
\end{tabular}

Water requirement of wheat, at initial stage, varied between 12.92 to15.75 mm (Table 3). The water requirements were $46.875 \mathrm{~mm}$ and dependable rainfall $(75 \%)$ were $0 \mathrm{~mm}$, necessitating supplemental irrigation. The water requirements at this stage more or less same varying from 42.94 to $46.69 \mathrm{~mm}$. Highest water requirements of wheat at mid-season stage were $139.75 \mathrm{~mm}$ followed by development stage, initial stage and late season stage, respectively. Seventy five percent dependable rainfalls were 13 $\mathrm{mm}$ only in this district. So, supplemental irrigation is needed for growing crops. Total water requirements of wheat were $208.745 \mathrm{~mm}$ and $75 \%$ dependable corresponding rainfall were $39 \mathrm{~mm}$. Similar result was found by Hassan and Sarkar (1994).

Initial stage water requirement of potato were $31.68 \mathrm{~mm}$ and the dependable rainfall were $94 \mathrm{~mm}$. (Table 3). At development stage, water requirements were $65.03 \mathrm{~mm}$ and dependable rainfall were 44 $\mathrm{mm}$. At mid-season, highest water requirements were found $86.25 \mathrm{~mm}$. On the other hand, $75 \%$ dependable rainfall were zero. Supplemental irrigation must be provided for proper yield. In late season stage, water requirements were approximately similar to initial stage. But the dependable rainfall $(75 \%)$ were not sufficient which was only 10 . So, it necessitates supplemental irrigation. Total water requirements of potato were $214.84 \mathrm{~mm}$. For high yields the crop water requirements for a 120 to 150 day potato are 500 to $700 \mathrm{~mm}$ depending on climate (Doorenbos et al., 1979). Total water requirement of potato was $154.2 \mathrm{~mm}$ at different growth stages (Hassan et al., 2002). For Brinjal, Tomato, Groundnut (Rabi), supplemental irrigation is to be provided at initial, development and mid-season stages for the study area. Total water requirements of tomato were found to be $413.78 \mathrm{~mm}$. There is a good agreement between the results found for the study area and that reported by Doorenbos et al. (1979). Lentil, groundnut, potato, mustard, chickpea, and wheat produced reasonable yield utilizing 65, 70, 100, 60, 65 and $100 \mathrm{~mm}$ water, respectively (Rahman and Islam, 1991). From the study, it is clear that maize (Kharif-I) suffered from moisture stress at initial and development stages. The development or reproductive phases of maize is the critical growth stage. Thus, supplemental irrigation must be provided to maize to get good yield of maize. The study revealed that there is a great scope for rain water harvesting and watershed management in the study areas.

\section{Conclusion}

Rainfall is an important resource for crop production under rainfed crop culture. About $70 \%$ of the annual rainfall occurred during the months of June to September and $90 \%$ during April to October. Maximum rainfall occurred in July and minimum in January. The number of rainy days per month at $75 \%$ probability level was 20 in July and in December it reduced to zero. The highest potential evapotranspiration at $75 \%$ probability level was $4.6 \mathrm{~mm}$ per day in April and the lowest was $2.4 \mathrm{~mm}$ per day in January. Water balance studies indicated that irrigation was necessary for successful crop production during November through March due to non-availability of sufficient amount of rainfall and high atmospheric evaporative demand of water by crops. The period between April to October was found to be surplus period (rainfall> PET). The major Kharif-I and Kharif-II crops during April to October is rice, and there is no problem of water except special years, when dry spell continued for long time affecting growth and development of crop. The months from November to March and, in some cases upto April is deficit period (rainfall< PET). After harvesting the transplanted Aman rice at the end of October, farmers could grow pulse, oilseeds like mustard, groundnut, or wheat. 


\section{References}

Ali, M.H., Amin, M.G.M. and Hoque, A.K.M.R. 2005. Probability Analysis of Monsoon and Off-monsoon Rainfall and Crop Planning in Bangladesh. Bangladesh J. Environ. Sci. 11(2): 290-295.

Allen, R.G., Luis, S.P., Dirk, R. and Martin, S. 1998. Crop Evapotranspiration -Guidelines for Computing Crop Water Requirements. FAO Irrigation and Drainage Paper No. 56, Food and Agriculture Organization of the United Nations, Rome, Italy.

BBS (Bangladesh Bureau of Statistics). 2004. Statistical Year Book of Bangladesh. Govt. of the People's Republic of Bangladesh. Dhaka, Bangladesh. pp. 135-139.

Doorenbos, J. and Pruitt, W.C. 1977. Crop Water Requirements, Irrigation and Drainage Paper No. 24, FAO, Rome, Italy.

Doorenbos, J., Kassam, A.H., Bentvelsen, C.I.M., Branscheid, V., Plusje, J.M.G.A., Smith, M., Uittenbogaard, G.O. and Van der wal, H.K.. 1979. Yield Response to Water. FAO Irrigation and Drainage Paper. 33, Rome, Italy.

Hassan, A.A. and Sarkar, A.A. 1994. Assessment of Irrigation Schedules of Field Crops Using Neutron Moisture Meter to Increase Effective Use of Water in Irrigation Projects. IAEA Research Contract-6985/RB Research Report. BINA/Ag.Engg./2 p. 13.

Hassan, A.A., Sarkar, A.A., Ali, M.H. and Karim, N.N. 2002. Effect of Deficit Irrigation at Different Growth Stages on the Yield of Potato. Pakistan J. Biol. Sci. 5(2): 128-134.

Hossain, M.A., Shirajzi, S.M., Talukder, M.S.U., Hye, M.A. and Gosh, A.K. 2001. The Impact of Climate Changes on Crop Production. Bangladesh J. Agril. Sci., 28 (1): 115-124.

Khan, M.B.R., Moinuddin, M. and Sarker, P.K. 1991. Some Probability Aspects of Rainfall in Gazipur. Bangladesh J. Agri.16:61-70.

Khan. C.M.A. and Bhuiyan, S.I. 1985. Effect of Location on Water Adequacy in an Irrigated Area. Bangladesh J. Agril. Sci. 10(2): 143-152.

Manola. 1978. Agroclimatic Survey of Bangladesh. Bangladesh Rice Research Institute, Joydebpur, Dhaka.

Rahman, S.M. and Islam, A. 1991. Yield and Water Relations of Wheat as Influenced by Irrigation and Depth of Tillage. Irri. Sci., 12: 67-71.

Talukder, M.S.U. 1982. Estimation of Some Agroclimatological Parameters from Standard Meteorological Observations in Bangladesh. Physics Department. The Royal Veterinary and Agricultural University, Copenhagen, Denmark. A Research Report. p. 1-96.

Talukder, M.S.U., Ali, S.M.A., Huq, M.M. and Hossain, M.A. 1988. A Study on Rainfall Pattern of Bangladesh. Bangladesh J. Agril. Sci. 15(23): 217-224.

Vishwakarma, S.K., Rangade, D.H., Paradkar, V.K., Jain, L.K. and Tomar, A.S. 2000. Probability Analysis of Wet and Dry Spells for Agricultural Planning at Chhindrwara, India. Ind. J. Agril. Sci., 70(10): 719-721.

Weibull, W. 1939. A Statistical Theory of the Strength of Materials. Ing. Vetenskapsaked. Handa (stocks). Vol. 151. p. 15. 